\title{
A Study of the Efficiencies of Maize and Wheat Futures Markets in India
}

\author{
Zelda A. Efe-Omojevwe \\ Department of Agricultural Economics, Tamil Nadu Agricultural University, Coimbatore-641 003, \\ Tamil Nadu State, India.
}

\begin{abstract}
This paper studies the futures markets for maize and wheat in India in order to determine their efficiencies. Cointegration and error correction models are used to determine the presence of cointegration and short-run equilibrium relationship between the futures and spot prices. The convergence of the futures and spot price series suggests that futures markets play the expected roles of price discovery and risk management. Although the futures market is found to be an unbiased predictor of future spot price, it is weakly inefficient for both commodities because past futures and spot prices had significant impact on the current spot prices. Also, price volatility clustering is not found in the price series which is an indication that price movements are due to normal fundamentals of demand and supply. On the basis of price discovery and risk management, the study advocates for more participation in the futures market and the formulation of policies that would enhance greater working efficiency of the futures markets.
\end{abstract}

Key words: Futures, efficiency, maize, wheat, volatility, India and cointegration.

\section{Introduction}

Futures contract is an agreement for buying or selling a commodity for an agreed predetermined delivery price at a specific future time while the futures market is the place or exchange where people can trade standardized futures contracts. The main participants in the futures market are the hedgers (producers and consumers) and traders (speculators and arbitrageurs). Price risk management and price discovery are the two major functions of the futures market. Risk management is the transfer of price risk from hedgers to speculators who provide liquidity in the market in the course of seeking profits while price discovery is when there is convergence of the futures and spot prices which is an indication that available information are incorporated into the futures price. The futures market is said to be inefficient if is unable to perform either of or both afore mentioned functions.

Considering the fact that agricultural commodities are mostly prone to high price volatility as a result of market fundamentals such as yield fluctuation dictated by weather conditions, demand and supply elasticity with respect to price as well as the time lag of production activities that sometimes result in a hog cycle, futures markets have thus been deemed important. For instance, agribusinesses and producers are faced with a diverse array of marketing and production alternatives, hence the need to have knowledge of prices that will likely prevail at future spots in order that they can make informed decisions among competing commodities and smoothen their earnings as well as plan costs of commodity storage. Commodity price forecasts are reportedly key inputs to macroeconomic policy planning and formulation. ${ }^{[1]}$ Also, futures markets help consumers to make informed decisions on their budgets; reduce volatility in expenditure by knowing when and where to make purchases. In addition, the futures trading help exporters and importers to quote realistic prices and to choose competitive markets for their transactions. For these reasons, it becomes imperative to study the futures market.

Agricultural commodities futures in India are considered important because the country has transformed from being a net importer to a net exporter of many commodities as a result of the green revolution of the 1960s. India has 5 national exchanges and 21 regional exchanges for commodity derivatives trading. Besides, commodity derivative in India started as far back as 1875 with the advent of the Bombay Trade Association Ltd futures trading in cotton.: ${ }_{[}^{[2]}$ The National Commodity Derivatives Exchange Limited (NCDEX) from which the historical price data for the study was obtained is one of the most important commodity exchanges in India. It was incorporated as a public limited company on April 2003 under the "Companies Act 1956" and it commenced its operations on December 15, 2003. It is a national-level technology driven demutualised online commodity exchange that is headquartered in Mumbai and offers facilities to members from the centres located throughout India. Futures' trading is allowed in all commodities except tur, urad and rice which were suspended in 2007 from futures trading; however, options' trading is not allowed.

${ }^{1}$ B. Chakriya, and A.M. Husain, Forecasting commodity prices: Futures versus judgment. IMF Working Paper, WP/04/41, 2004

${ }^{2}$ N.L. Ahuja, Commodity derivatives market in India: Development, regulation and future prospects. International Research. Journal of

Finance and Economic,s 2, 2006, 154-162. 
Agriculture employs about 57 per cent of the Indian labour force. ${ }^{[2]}$ For a sector that is highly influenced by weather, biological elements, price volatility and yet provides much employment; it is important that the income of the people are stabilized through the risk management window that futures market offers. The two agricultural commodities are selected for their peculiarity; maize is the world's third most important crop after wheat and rice. About 75 per cent of India maize production is used by the poultry feed sector; about 20 per cent by the starch industry and the rest is used for human consumption and livestock. There has been an enormous demand for Indian maize in the Asian countries and its price tends to peak during the months of April to June and starts declining from the month of July. Wheat is mostly cultivated as a cash crop and also used as a common food staple. India has the largest area in the world under wheat and its production makes up about 35 per cent of India's total food grain production of 210-212 million tons in a year. The major importers of Indian wheat are from South-east Asia and Gulf countries. More so, the price of wheat peaks around September to January but declines from February. Given the importance of these crops, this paper seeks to find if their futures markets are efficient.

Market efficiency is the ability of commodity prices to quickly and fully reflect all the underlying public and private information so as to hedge away high gains or losses. It indicates that prices reflect all publicly available information and as such, profitable strategies cannot exist. ${ }^{[3]}$ Efficient market hypothesis also requires that all past information should already be incorporated into the current futures price and therefore past futures and spot prices should not have any significant effect on the future spot price. ${ }^{[4]}$ The efficient market hypotheses are made up of the weak, semi-strong and strong forms. Tests for weak-form efficiency rely on information embodied in past prices while tests for semi-strong form efficiency use all publicly available information on prices and other relevant information.

Some studies of agricultural futures market used Johansen cointegration procedure to test for long-run efficiency and unbiasedness as well as the application of the Error Correction Model (ECM) to test for short-run inefficiencies and pricing bias. ${ }^{[4]}$ Research has shown the futures market efficient and unbiased in the long run but with some inefficiencies and pricing biases in the form of dynamic lag structure in the short run. The futures market of corn, soybean and wheat in the United States were studied and the presence of weak form market inefficiency was identified; agents were able to profit from information embodied in past prices. ${ }^{[3]}$

Market failure and inefficiency which result in excessive market fluctuations have been stated as some of the reasons for the establishment of futures market. ${ }^{[5]}$ Futures prices may deviate from future spot prices for several reasons such as government price intervention, unexpected changes in foreign exchange rate and significant changes in the volume of demand and supply. It was found that futures tend to be inefficient given a longer forecast period. ${ }^{[6]}$ In a study of cattle futures, it was also opined that futures prices are efficient forecasters of spot prices with near maturity dates. ${ }^{[7]}$ Market inefficiency also arises when there is high price volatility even though an efficient futures market is expected to exhibit some level of volatility because prices must change to reflect new information flow. This is why, in a free economy, volatility of prices is directly related to the flow of information, such that a market which reacts faster is assumed to be better ${ }^{[8]}$ Price volatility occurs when prices change by significant amount over a short period of time. The volatility in agricultural prices is partially or fully managed by the locking-in of prices (hedging). Although agricultural price volatility cannot be eliminated, its variability can be mitigated such that price volatility reflects market fundamentals and do not convey wrong signals as a result of wrong information, speculation or panic. ${ }^{[9]}$ The lead-lag relationships between futures trading activity and cash price volatility were examined and it was found that unexpected futures trade volume causes unidirectional cash price volatility for most commodities, but there was weak causal feedback between open interest and cash price volatility. ${ }^{[10]}$ On this note, the study determines the presence of volatility and the reliability of futures prices as good predictors of the spot prices of maize and wheat commodities. The paper starts with introduction of the agricultural futures market and its relevance in

${ }^{3}$ J.A.Wiseman, M.A.. Darroch, and G.F. Ortmann, Testing the efficiency of the South African futures market for white maize. Agrekon, 38(3), 1999, 321-335.

${ }^{4}$ A.M. McKenzie and M.T. Holt, Market efficiency in agricultural futures markets. Applied Economics, 34(12), 2002, 1519-1532.

${ }^{5}$ S.A. Hosseini-Yekan, M. Zibaei, and D.E. Allen, The initial specification of viable futures contracts: The use of a new computational method of value at risk in Iranian agricultural commodities market. Journal of Agricultural Science Technology, 12, 2010, 535-548.

${ }^{6}$ T.A. Kofi, A framework for comparing the efficiency of futures markets. American. Journal of. Agricultural Economic, 55, 1973, 584-59.

${ }^{7}$ R.M. Leuthold, The price performance on the futures market of a non -storable commodity: Live beef cattle. American. Journal of Agricultural Economics 56, 1974, 271-279.

${ }^{8}$ M.T. Shihabudheen, and P. Padhi, Price discovery and volatility spill over effect in Indian commodity market. Indian Journal of Agricultural Economics, 65(1), 2010, 101-117.

${ }^{9} \mathrm{FAO}$, IFAD, IMF, OECD, UNCTAD, WFP, World Bank, the WTO, IFPRI, UN HLTF, Price volatility in food and agricultural markets: policy responses. Policy Report, 2 June, 2011.

${ }^{10}$ J.Yang, R.B. Balyeat, and D.J. Leatham, Futures trading activity and commodity cash price volatility. Journal of Business Finance \& Accounting, 32(1) \& (2), 2005, 297-323. 
India. Then it reviews selected literature on the study of futures market. The proposed methodology to analyze the study objectives is presented, the results of the analyses are discussed and the paper ends with conclusion.

\section{Methodology}

The study uses data obtained from the database of the Indian National Commodity Derivative Exchange (NCDEX) ${ }^{[11]}$ on the futures trading of the commodities for the period of January 2006 to June 2011. The daily price data is converted into monthly price data. Stationarity of the data is determined with a unit root test using the Augmented-Dickey Fuller (ADF) method. Augmented Engle-Granger (AEG) cointegration test of unit root is applied on the obtained residuals of the long-term equilibrium regression. The existence of cointegration means the price relationship between futures and spot can be adequately represented by an error correction model (ECM). This study tests for weak-form efficiency as is mostly done for commodity time series that are mostly non-stationary and hypothesizes that the futures markets for maize and wheat in India are efficient and serve the twin purposes of risk management and price discovery.

\section{Cointegration Regression}

Unit Root Model: $\Delta \mathrm{Y}_{\mathrm{it}}=\alpha_{0}+\alpha_{1} \mathrm{Y}_{\mathrm{it}-1}+\alpha_{2} \Delta \mathrm{Y}_{\mathrm{it}-1}+\varepsilon_{\mathrm{t}}$

The cointegrating regression: $\mathrm{SP}_{\mathrm{it}}=\beta_{\mathrm{i} 1}+\beta_{2} \mathrm{FP}_{\mathrm{it}}+\mathrm{U}_{\mathrm{it}}$

Where, SP is spot price and FP is futures price. It can be inferred that the futures market is unbiased and efficient if the null hypothesis: $\beta_{1}=0$ and $\beta_{2}=1$ of (2) is not rejected. Also, since the efficiency of the futures market implies that the current futures prices reflect all past or historic information, the lag terms of the futures and spot are reflected in the model.

$\mathrm{SP}_{\mathrm{it}}=\beta_{\mathrm{i} 1}+\beta_{2} \mathrm{FP}_{\mathrm{it}}+\beta_{3} \mathrm{FP}_{\mathrm{it}-1}+\beta_{4} \mathrm{SP}_{\mathrm{it}-1}+\mathrm{U}_{\mathrm{it}}$

The futures is regarded as efficient if the null hypothesis: $\beta_{3}=\beta_{4}=0$ of (3) is not rejected, otherwise it is not.

ECM Model: $\Delta \mathrm{SP}_{\mathrm{it}}=\alpha_{0}+\alpha_{1} \Delta \mathrm{FP}_{\mathrm{it}}+\alpha_{2} \mathrm{U}_{\mathrm{it}-1}+\varepsilon_{\mathrm{t}}$

The ECM determines the short run disequilibrium relationship between the futures and spots prices.

\section{Estimation of Volatility}

Price volatility is determined with an ARCH (2) model ${ }^{[12]}$

$\mathrm{u}_{\mathrm{t}}^{2}=\alpha_{0}+\alpha_{1} \mathrm{u}_{\mathrm{t}-1}^{2}+\alpha_{2} \mathrm{u}_{\mathrm{t}-2}^{2}+\ldots .+\alpha_{\mathrm{p}} \mathrm{u}_{\mathrm{t}-\mathrm{p}}^{2}$

Taking $\mathrm{FP}_{\mathrm{t}}^{*}=\log$ of $\mathrm{FP}_{\mathrm{t}}$, and $\mathrm{X}_{\mathrm{t}}=\Delta \mathrm{FP}_{\mathrm{t}}^{*}-\Delta \overline{\mathrm{FP}}_{\mathrm{t}}^{*}$

$\mathrm{X}^{2}{ }_{\mathrm{t}}$ is then taken as a measure of volatility:

$\mathrm{X}_{\mathrm{t}}^{2}=\beta_{0}+\beta_{1} \mathrm{X}_{\mathrm{t}-1}^{2}+\beta_{2} \mathrm{X}_{\mathrm{t}-2}^{2}+\mathrm{U}_{\mathrm{t}}$

Test of ARCH Effect: $\Delta \mathrm{FP}_{\mathrm{t}}^{*}=\beta_{0}+\mathrm{U}_{\mathrm{t}}$

Where $\beta_{0}$ is a constant and the obtained $\mathrm{U}_{\mathrm{t}}$ are regressed as:

$\mathrm{U}_{\mathrm{t}}^{2}=\beta_{0}+\beta_{1} \mathrm{U}_{\mathrm{t}-1}^{2}+\beta_{2} \mathrm{U}_{\mathrm{t}-2}^{2}$

A joint F-test is used to determine if $\beta_{1}=\beta_{2}=0$

\section{Results And Discussion}

The coefficients of variation in the spots and futures prices as shown in Table 1 reflect the degree of variability within the price series and it is higher in the wheat commodity than maize; this is attributed to the ban on wheat futures during the period of 2007-2009. It was found that maize and wheat futures are a little more unstable than their spots. The distribution of futures and spot prices of maize were fairly symmetrical while those of wheat were negatively skewed. The futures price of wheat were platykurtic but the price series of maize and wheat spot prices were more peaked (leptokurtic) indicating a lower variance.

Table 1. Descriptive Statistics of the Spot and Futures Prices during the Period of 2006-2011.

\begin{tabular}{|c|c|c|c|c|c|c|}
\hline Commodity & prices & $\mathbf{N}$ & Mean & $\begin{array}{c}\text { Coefficient of } \\
\text { variation }\end{array}$ & skewness & kurtosis \\
\hline \multirow{2}{*}{ Maize } & Futures & 66 & 862.21 & 20.91 & 0.51 & 0.37 \\
\cline { 2 - 7 } & Spot & 66 & 840.63 & 20.85 & 0.46 & 0.58 \\
\hline \multirow{2}{*}{ Wheat } & Futures & 66 & 787.84 & 68.97 & -0.66 & -1.35 \\
\cline { 2 - 7 } & Spot & 66 & 784.60 & 68.62 & -0.68 & 0.58 \\
\hline
\end{tabular}

The null hypothesis of non-stationarity of the price series was not rejected as indicated by the result in Table 2. A test for unbiasedness and efficiency on the results presented in Table 3 using (2) showed that the null hypotheses are not rejected for both commodities; suggesting that the futures market is an unbiased and efficient

\footnotetext{
${ }^{11}$ National Commodity Derivatives Exchange Limited. http://www.ncdex.com.

${ }^{12}$ D.N. Gujarati, and Sangeetha, Basic econometrics (Tata McGraw-Hill Publishing Company Limited, New Delhi, 2007).
} 
predictor of the spot prices of the commodities. Also, futures price is shown to have a significant positive effect on the spot price for both commodities.

Table 2. Augmented Dickey-Fuller Method of Test for Unit Root in the Price Series

\begin{tabular}{|l|c|c|}
\hline \multicolumn{2}{|l|}{ Dependent variable: $\Delta \mathrm{Y}_{\text {it }}$} \\
\hline Parameters & Maize & Wheat \\
\hline$\alpha_{1} \mathrm{FP}_{\mathrm{it}-1}$ & $0.00(-0.006)$ & $0.061(-1.318)$ \\
\hline$\alpha_{1} \mathrm{SP}_{\mathrm{it}-1}$ & $-0.015(-0.353)$ & $-0.063(-1.377)$ \\
\hline
\end{tabular}

Figures within parentheses are $\mathrm{t}$-values and the DF critical value is -2.89

Table 3. Statistics of Cointegration Regression between the Futures and Spot Prices

\begin{tabular}{|l|c|c|}
\hline \multicolumn{2}{|l|}{ Dependent variable: Spot price } \\
\hline Parameters & Maize & Wheat \\
\hline Intercept & $33.349(1.161)$ & $10.449(0.685)$ \\
\hline$\beta_{2} \mathrm{FP}_{\text {it }}$ & $0.936(28.692)^{*}$ & $0.983(61.459)^{*}$ \\
\hline
\end{tabular}

*Significant at the $5 \% \mathrm{t}$-critical value of 1.658

Maize

Test of unbiasedness: $\mathrm{H}_{0}: \beta_{1}=0$;

Using $\beta_{1} \pm \mathrm{t}_{\alpha / 2}$ se $\left(\beta_{1}\right)$, Then $\operatorname{Pr}\left[0-2(28.735) \leq \beta_{1} \leq 0+2(28.735)\right]=1-\alpha$

$=-57.47 \leq \beta_{1} \leq 57.47$.

Test of Efficiency: $\mathrm{H}_{0}: \beta_{2}=1$

$\operatorname{Pr}\left[1-2(0.033) \leq \beta_{2} \leq 1+2(0.033)\right]=1-\alpha$

$=0.934 \leq \beta_{2} \leq 1.066$

Wheat

Test of unbiasedness: $\operatorname{Pr}\left[0-2(15.264) \leq \beta_{1} \leq 0+2(15.264)\right]=1-\alpha$

$=-30.528 \leq \beta_{1} \leq 30.528$.

Test of Efficiency: $\mathrm{H}_{0}: \beta_{2}=1$

$\operatorname{Pr}\left[1-2(0.016) \leq \beta_{2} \leq 1+2(0.016)\right]=1-\alpha$

$=0.968 \leq \beta_{2} \leq 1.032$

The cointegration test showed that the coefficients of the lagged residual terms as presented in Table 4 for both commodities were significant and had the expected negative signs and the null hypothesis of nonstationarity was rejected implying that the futures and spot series are cointegrated and therefore converges. However, literature states that cointegration is only a necessary but not a sufficient condition for market efficiency ${ }_{2}^{[4]}$ Thus a further test on the past prices as shown in Table 5 indicated that past futures and spot prices were simultaneously significantly different from zero. Which means the null hypothesis that $\beta_{3}=\beta_{4}=0$ was rejected and the market was found to be weakly inefficient. In other words, past prices especially the past spot prices provided additional information that could be used to predict future spot prices.

Table 4. Statistics of Engle Granger Unit Root Test of Cointegration between Futures and Spot Prices.

\begin{tabular}{|l|c|c|}
\hline Dependent variable: $\Delta \mathrm{U}_{\text {it }}$ & Maize & Wheat \\
\hline Parameters & $0.754(0.155)$ & $0.541(-7.149)$ \\
\hline Intercept & $-0.487(-4.198)^{*}$ & $-0.533(-7.149)^{*}$ \\
\hline$\delta_{1} \mathrm{U}_{\text {it-1 }}$ & $0.194(1.411)$ & $0.541(4.524)^{*}$ \\
\hline$\delta_{2} \Delta \mathrm{U}_{\text {it-1 }}$ &
\end{tabular}

* Significant at the Dickey-Fuller critical value of -2.89

Table 5. Weak-form Efficiency Test

\begin{tabular}{|l|c|c|}
\hline \multicolumn{3}{|l|}{ Dependent variable: Spot price } \\
\hline Parameters & Maize & Wheat \\
\hline Intercept & $-4.875(-0.202)$ & $-2.677(-0.269)$ \\
\hline$\beta_{2} \mathrm{FP}_{\text {it }}$ & $0.669(6.144)^{*}$ & $0.951(32.721)^{*}$ \\
\hline$\beta_{3} \mathrm{FP}_{\text {it-1 }}$ & $-0.220(-1.407)$ & $-0.590(-6.937)^{*}$ \\
\hline$\beta_{4} \mathrm{SP}_{\text {it-1 }}$ & $0.551(5.464)^{*}$ & $0.636(7.903)^{*}$ \\
\hline F-stat & $436.018^{*}$ & $3083^{*}$ \\
\hline
\end{tabular}

*significant at the $5 \% \mathrm{t}$-critical value of 1.658

In the short run, using the ECM (4), futures prices were found to have a positive impact on the spot prices. The significant coefficient of the error correction terms in Table 6 indicated disequilibrium but the absolute values of $\alpha_{2}(-0.45$ and -0.36$)$ for maize and wheat respectively had the expected negative signs 
signifying the convergence between the spot and futures prices and the restoration of equilibrium in approximately two and three periods for the respective commodities. Maize spot prices thus adjusts faster than wheat but wheat futures has a higher short run equilibrium changes $\alpha_{1}(0.95)$.

Table 6. Estimates of Error Correction Model

\begin{tabular}{|l|c|c|}
\hline \multicolumn{3}{|l|}{ Dependent variable: $\Delta$ SP } \\
\hline Parameters & Maize & Wheat \\
\hline Intercept & $3.795(0.791)$ & $-3.867(-0.698)$ \\
\hline$\alpha_{1} \Delta \mathrm{FP}_{\mathrm{it}}$ & $0.669(6.149)^{*}$ & $0.950(33.366)^{*}$ \\
\hline$\alpha_{2} \mathrm{U}_{\mathrm{it}-1}$ & $-0.454(-4.504)^{*}$ & $-0.364(-4.565)^{*}$ \\
\hline
\end{tabular}

*significant at the $5 \% \mathrm{t}$-critical value of 1.658

In testing for volatility, a positive coefficient of the second lagged term $\beta_{2}$ as presented in Table 7 suggests that a previous period high volatility will continue to be high in the current period and there will be volatility clustering but if the previous lagged term $\beta_{1}$ is zero, then there is no volatility clustering. The null hypothesis of no volatility clustering was not rejected as there was no observed individual or joint significance of the lagged volatility variables for the two commodities. This means price movements are more likely due to normal forces of demand and supply and not speculative activities or herding.

Table 7. Estimation of Volatility

\begin{tabular}{|l|c|c|}
\hline \multicolumn{3}{|l|}{ Dependent variable: $\mathrm{X}_{\mathrm{t}}^{2}$} \\
\hline Parameters & Maize & Wheat \\
\hline$\beta_{1} \mathrm{X}_{\mathrm{t}-1}^{2}$ & $0.052(0.401)$ & $-0.034(-0.263)$ \\
\hline$\beta_{2} \mathrm{X}_{\mathrm{t}-2}$ & $0.041(0.319)$ & $-0.034(-0.263)$ \\
\hline
\end{tabular}

\section{Conclusion}

The study set out to determine if the futures market for maize and wheat in India were efficient. It was inferred from the descriptive statistics that the variability between the futures and spot prices suggests that the maize and wheat futures markets were inefficient. Cointegration as a necessary but not sufficient condition for market efficiency is found between the spot and futures prices of the individually non-stationary series. The presence of cointegration is an indication of interdependency between the price series and it supports the findings of unbiasedness of the futures price in predicting the future spot prices. Consequently, the futures market is an optimal forecaster of future spot rates and is able to play the role of price discovery. The convergence of the futures and spot prices is reinforced by the negative error correction terms that help to minimise losses and gains in futures contract payments as contract maturity draws close. The futures markets were found to be weakly inefficient as they contained additional information that traders could use to make additional gains.

Although an efficient market must exhibit some level of volatility there was no significant price volatility. The presence of convergence between the series may have eliminated significant price volatility. The study shows that inefficiency is not always caused by volatility because even though there was no significant volatility, the market was weakly inefficient. The findings are relevant to the formulation and implementation of policies that would influence the use of the futures markets. It is recommended that increased effort be made to encourage the use of the futures market through public sensitization and training. This will reduce agricultural income risk. Participants of the Indian NCDEX can adequately use past prices or current futures prices to predict the future spot prices and make informed decisions about their time and point of sale or purchase, depending on the commodities basis (difference between a given location cash price and the futures price of that commodity).

\section{References}

[1] A.M. Chakriya, and A.M. Husain, Forecasting commodity prices: Futures versus judgment. IMF Working Paper, WP/04/41, 2004.

[2] N.L. Ahuja, Commodity derivatives market in India: Development, regulation and future prospects. International Research. Journal of Finance and Economics 2, 2006, 154-162.

[3] J.A.Wiseman, M.A. Darroch, and G.F. Ortmann, Testing the efficiency of the South African futures market for white maize. Agrekon, 38(3), 1999, 321-335.

[4] A.M. McKenzie, and M.T. Holt, Market efficiency in agricultural futures markets. Applied Economics 34(12), 2002, 1519-1532.

[5] S.A.. Hosseini-Yekan, M. Zibaei, and D.E. Allen, The initial specification of viable futures contracts: The use of a new computational method of value at risk in Iranian agricultural commodities market. Journal of Agricultural Science Technology,12, 2010, 535-548.

[6] T.A. Kofi, A framework for comparing the efficiency of futures markets. American Journal Agricultural Economics, 55, 1973, 58459 .

[7] R.M. Leuthold, The price performance on the futures market of a non -storable commodity: Live beef cattle. American Journal 
Agricultural Economics. 56, 1974, 271-279.

[8] M.T. Shihabudheen, and P. Padhi, Price discovery and volatility spill over effect in Indian commodity market. Indian Journal of Agricultural Economics, 65(1), 2010, 101-117.

[9] FAO, IFAD, IMF, OECD, UNCTAD, WFP, World Bank, the WTO, IFPRI, UN HLTF, Price volatility in food and agricultural markets: policy responses. Policy Report, 2 June, 2011.

[10] J. Yang, R.B. Balyeat, and D.J. Leatham, Futures trading activity and commodity cash price volatility. Journal of Business Finance \& Account. 32(1) \&(2), 2005, 297-323.

[11] National Commodity Derivatives Exchange Limited. http://www.ncdex.com.

[12] D.N. Gujarati, and Sangeetha, Basic econometrics (Tata McGraw-Hill Publishing Company Limited, New Delhi, 2007). 